\title{
A Decade Later: The Legacy of the Supreme Court of Canada's Health Services Decision on Workers' Rights
}

\author{
Brad Walchuk, Brock University, Canada
}

"...do not interfere in free collective bargaining. Do not mess with workers' rights" (Fred Habn, President, Canadian Union of Public Employees, 2017).

\begin{abstract}
The year 2017 marked the ten-year anniversary of the Health Services case, a precedent-setting decision by the Supreme Court of Canada that ruled collective bargaining is protected by the Canadian Charter of Rights and Freedoms. This article explores the impact and legacy of BC Health Services, and finds that while workers' constitutional rights have been expanded under the Charter over the past decade, governments nevertheless continue to violate these rights. It concludes that the legacy of the case is not an enhanced level of protection for these rights to be enjoyed fully, but rather that the default option has been and will continue to be a financial penalty for the state in instances in which they violate workers' rights.
\end{abstract}

\section{KEYWORDS}

labour rights; Canadian Charter of Rights and Freedoms; human rights; health services

\section{Introduction}

The tenth anniversary of a historic decision by the Supreme Court of Canada occurred in June 2017. In that case - Health Services and Support-Facilities Subsector Bargaining Association v. British Columbia. (2007). 2 S.C.R. 391, 2007 SCC 27, hereafter referred to as BC Health Services - the Court found that access to collective bargaining was protected by the "fundamental freedoms" section (s. 2(d) of the Canadian Charter of Rights and Freedoms). This ruling appeared to have given significant weight to the construction of labour rights as human rights, a connection made in the early part of the twentyfirst century (Adams, 2006; Fudge, 2006). The decision also appeared to give a significant legal boost to a movement that had endured a steady erosion of collective bargaining rights and union density in the decade preceding it (Panitch and Swartz, 2003; CFLR, 2017), though that legal boost has not translated into overall union growth. Over a decade after this decision occurred, it is worth reflecting on $B C$ Health Services to determine its implications for the labour movement, its members and its prospects for future growth.

This article argues that despite the potential to ensure the realisation of free and fair collective bargaining offered by $B C$ Health Services, there has been a continued intrusion into the bargaining rights of unionised workers and a lack of labour movement growth stemming from the legal expansion of rights. Governments have continued to infringe against the right to bargain collectively held by unionised workers, and the legal protection of bargaining rights has not led to 
significant numbers of non-unionised workers joining the labour movement. That said, when the rights of existing union members are violated, there are now financial penalties that the state must pay to those union members whose rights were infringed. In short, this highlights the limitations of a legal strategy and the need to for unions to balance legal strategies versus those focused on the organisation and mobilisation of members.

The first part of this article examines the concept of workers' rights as human rights and the accompanying legal strategy that surrounded this construction. The second part provides an analysis of the lead-up to the BC Health Services case and the Court's decision. The final section of the article considers the impact that this decision has had over the past decade in light of the body of jurisprudence that has arisen from it and its overall limitations on advancing collective bargaining rights and increasing workers' organising capacities. It concludes that while it is potentially more costly to violate rights than it previously was, governments are willing to gamble that short-term political gain and the potential for long-term savings outweighs violating bargaining rights and the right to strike.

While the geographical scope of the article is limited to Canada, the broader theoretical conclusions about labour's reliance on the judiciary and the construction of labour rights as human rights is universally applicable. So too is a reflection on the balance between a legal strategy and one based on mobilisation. With legal strategies becoming increasingly commonplace as labour struggles to advance in an era of neo-liberalism, unions outside Canada can learn a great deal from the Canadian experience with the limitations of a rights-based strategy. In so doing, this article not only contributes directly to the literature on the construction of labour rights as human rights, but also to a broader body of literature on union revitalisation strategies (Behrens, Hamann and Hurd, 2004; Frege and Kelly, 2004; Lévesque and Murray, 2010).

\section{Labour Rights as Human Rights}

The construction of labour rights - the rights to join a union, to strike and to bargain collectively - as human rights grew in popularity in the early part of the twenty-first century (Compa, 2000; Gross, 2003; Adams, 2006; Fudge, 2006). Roy Adams (2006: 15), one of the most forceful advocates of equating labour rights with human rights asserted, "the worker must not be treated as a commodity but instead as a human being with an inalienable right to dignified treatment". Lance Compa echoed a similar argument, noting:

...so long as worker organizing, collective bargaining, and the right to strike are seen only as economic disputes involving the exercise of power in pursuit of higher wages for employees or higher profits for employers, change is unlikely. Reformulating these issues as human rights concerns can begin a process of change (Compa, 2000: 17).

While for much of the history of organised labour in Canada these "rights" were not protected by legislation, this changed in 1945 through Privy Council Order 1003; they were enshrined in provincial law a few years later. Legislative rights, however, were contested: they could be advanced or repealed, but were never guaranteed.

The approach advocated by Adams (2006) and Compa (2000) asserts that the traditional activities of the labour movement are not simply policy preferences that can be subjected to the whims of elected politicians, but are activities deserving of being elevated to human rights. This approach entails using the legal system to advance and secure these rights. Derek Fudge (2006: 83), for example, argues the labour movement "need[s] a coordinated national strategy ... to use the 
judicial system to advance workers' rights in Canada, including joint legal research, communications strategies and financial support on the key cases".

The suggestion that labour rights are human rights is not universally agreed upon (Mandel, 1994; Brody, 2001; Lichtenstein, 2003; McCartin, 2005; Savage, 2008; Savage and Smith, 2017). These critics are not opposed to the advancement of workers' rights, but are instead critical of an overly legalistic and depoliticising model. For example, Larry Savage (2008) argues that constructing labour rights as human rights is problematic because it threatens to undermine classbased responses to neo-liberal globalisation, downplays the material dimension of workers' collective action and wrongly assumes that power flows from rights (see also Savage and Smith, 2017).

There have also been scholars with a more nuanced view, highlighting the potential gains associated with advancing labour rights as human rights, but at the same time sensitive to some of the concerns or limitations of this approach. In what he calls a "pragmatic approach" Walchuk (2008) argues that while organised labour should use the legal when advantageous, it cannot do so at the expense of electoral politics and rank-and-file activism. Nelson Lichtenstein (2003) has focused more on the impacts of the rights discourse and utilising the legal system to advance collective bargaining rights. He argues that for labour rights to have meaning, rank-and-file workers are forced to rely on union bureaucrats and labour lawyers, as opposed to their own active participation.

These competing theoretical viewpoints illustrate the complexities of a rights-based approach to collective bargaining. Largely, however, the labour movement in Canada (and elsewhere) has embraced constructing labour rights as human rights, especially since the turn of the twenty-first century. While this should not suggest that organised labour has abandoned its traditional avenues of resistance, it has certainly made increasing use of the legal arena. (For a detailed analysis, see Savage and Smith, 2017). Although this approach has been central to a revitalisation strategy pursued by Canadian unions, using the legal system has also been an avenue pursued by unions in Britain (Colling, 2009; Guillaume, 2015), Japan (Sugeno, 2015) and South Africa (IndustriALL, 2018). This avenue has also had drastic adverse effects on American unions (Liptak, 2018).

\section{The First Era of Labour and the Charter (1982 to the late 1990s)}

Post-Charter Canada (beginning in 1982) can be broken into two specific eras, at least for the purposes of organised labour's rights-based strategy. The first, beginning in 1982 with the passage of the Canadian Charter of Rights and Freedoms and ending in the late 1990s, saw the exclusion of workers' collective rights from the Charter and no real advancement of legal protections under it. Undeterred, however, labour continued to advance its rights-based approach in an attempt to secure collective rights for workers under the Charter.

Organised labour played no real role in the passage of the Charter in the early 1980s. Michael Mandel (1994: 261) suggested that unions were "asleep at the switch" in regard to its passage, while Joseph Weiler (1986: 213) has asserted that labour found the process to be "arcane". Despite this, labour realised shortly after the Charter's passage that it represented a potential tool, and attempted to advance the collective rights of workers through constitutional law.

In 1987, three separate cases - Reference Re Public Service Employee Relations Act (Alta.), RWDSU v. Saskatchewan and PSAC v. Canada - made their way to the Supreme Court of Canada, and established a problematic precedent for the labour movement. Reference Re Public Service Employee Relations Act (Alta.) involved a number of unions challenging legislation that sought to limit the scope of collective bargaining and prohibit work stoppages in the public sector. Unions that 
appeared before the Court argued that section 2(d) of the Charter - the fundamental freedoms clause - should be read in such a way as to include the right to bargain collectively and the right to strike. Freedom of association, they contended - which is explicitly protected by section $2(\mathrm{~d})$ - was sufficiently broad to provide constitutional protection to the right to bargain collectively and the right to strike. The Court did not agree.

The Court's majority decision asserted that "the rights for which constitutional protection is sought - the modern rights to bargain collectively and to strike, involving correlative duties or obligations resting on an employer - are not fundamental rights or freedoms" (para. 144). This meant, of course, that whatever "rights" had been provided by the legislature could also be repealed. The concept of "labour rights as human rights" appeared to be foreign to the Court at this point in time. The Court's highly progressive dissenting opinion, written by Chief Justice Dickson, asserted - unsuccessfully - that freedom of association rights protected the right to bargain collectively (paras. 119-30).

The Court then applied this rationale to PSAC v. Canada and RWDSU v. Saskatchewan, the two remaining cases in the Labour Trilogy. Following these decisions, the labour movement retreated from an aggressive rights-based strategy. The precedent established in the Labour Trilogy appeared to be clear: the Charter's fundamental freedoms offered no space for the collective exercise of workers' rights.

\section{The Second Era of Labour and the Charter (the late 1990s to 2007)}

By the late 1990s, however, organised labour revisited its rights-based approach and increasingly turned to the Charter to advance the collective rights of workers (Walchuk, 2008: 98; Smith and Savage, 2017). With little to lose, and limited options to advance rights, labour once again began to make appeals under section 2(d) of the Charter. In many ways, the rise of this legal strategy corresponded with declining union density in Canada, which sat at 37.6 per cent in 1981 and had declined to 33.9 per cent by 1999 (StatsCan, 2015, 2018).

In U.F.C.W., Local 1518 v. KMart Canada Ltd., locked-out unionised workers at one store began to distribute leaflets at other area KMart stores alleging unfair labour practices and urging customers to shop elsewhere. The peaceful activity was stopped via court injunction, and an appeal to the provincial labour board was dismissed. This prompted a legal challenge that made it all the way to the Supreme Court of Canada, alleging that the prohibition on leafleting violated the workers' right to freedom of expression. The Court agreed, noting, "The importance of freedom of expression during labour disputes cannot be overemphasized.... Leafleting is of fundamental importance for workers and has a very real social value" (para. 73). This marked the first time that a union had advanced a new right, however small, in the Charter era.

Four years after its decision in KMart, the issue of whether picketing was afforded constitutional protection was brought before the Court. During a legal strike against Pepsi-Cola, picketing had spread from the worksite to other locations, including retail outlets selling Pepsi made by replacement workers, the hotel that was housing replacement workers, and the homes of Pepsi management. This is commonly referred to as secondary picketing. The case - R.W.D.S.U., Local 558 v. Pepsi-Cola Beverages (West) Ltd. - proceeded to the Supreme Court, which ruled that secondary picketing was a constitutionally protected activity that could not be unreasonably infringed (para. 77).

The Court's decision in 2001 in Dunmore v. Ontario (Attorney General), 2001 SCC 94, [2001] 3 S.C.R. 1016 aided the assertion that workers' rights are human rights, albeit stopping short of asserting a constitutional right to bargain. In moving away from the narrower rationale of the 
Reference Re Public Service Employee Relations Act (Alta.), [1987] 1 S.C.R. 313 (known as Alberta Reference), the Court reasoned that collective workers' rights existed, though they were clear that this did not extend to the realm of collective bargaining. The Court found that a union "assumes a life of its own and develops needs and priorities that differ from those of its individual members", and continued that "trade unions develop needs and priorities that are distinct from those of their members individually, they cannot function if the law protects exclusively what might be the lawful activities of individuals" (para. 17). In so doing, it concluded that the law must recognise that certain union activities - including making collective representations to an employer and joining with other unions - were central to freedom of association.

Despite this, the Court went to great lengths to place limitations on this victory and to uphold the Alberta Reference. As the Court clearly articulated, "This is not to say that all such activities are protected by s. 2(d), nor that all collectivities are worthy of constitutional protection; indeed, this Court has repeatedly excluded the right to strike and collectively bargain from the protected ambit of s. 2" (para. 17, emphasis added). While the decision in Dunmore fell short of providing clear protection to a constitutional right to bargain collectively, it opened up space for such a proclamation through its expanded notion of collective rights.

The second era of labour's appeals to the Supreme Court offered an expanded notion of constitutionally protected freedoms for labour, and began to realise more fully the notion of labour rights as human rights. Despite these rights-based claims, however, union density continued to slip in Canada, a lower percentage of workers benefitted from these rights (StatsCan, 2015), and the percentage of workers engaged in strike activity decreased (Gender and Work Database, 2012). Additionally, the Court continued to deny that the right to bargain collectively was one protected by the Canadian Charter of Rights and Freedoms, which is why their decision to overturn twenty years of jurisprudence in the BC Health Services case in 2007 was all the more remarkable.

\section{BC Health Services (2007)}

In 2001, the provincial government in British Columbia passed the Health and Social Services Delivery Improvement Act. Among other things, this legislation facilitated extensive privatisation of public health care and eliminated various support services (leading to the loss of approximately 8000 unionised jobs). It also stripped anti-contracting-out provisions from previously negotiated collective agreements and eliminated labour force retraining programmes for newly unemployed workers (Lancaster House, 2007). The Act also made it illegal to discuss alternatives to privatisation with employers at the bargaining table, prompting the union to launch a rights-based Charter challenge (Walchuk, 2011).

In early 2004, the Hospital Employees' Union (HEU) called off a planned general strike and unilaterally reached an agreement with the government that retained a 15 per cent wage rollback (but no longer made it retroactive), limited further contracting out to 600 full-time equivalents, and provided an additional \$25 million in settlement pay (Isitt and Moroz, 2007: 104). In this sense, while union leaders bargained a deal, the conditions that brought it about were hardly free and fair. They explicitly forewent a militant strategy of membership mobilisation and instead opted for a legal strategy, relying on the courts and the Canadian Charter of Rights and Freedoms.

The judgment at the British Columbia Supreme Court dismissed the union's claim that the Charter provided them with a right to bargaining collectively. Building on the precedent established in the Alberta Reference, the trial judge dismissed the HEU's freedom of association claim, elaborating that "the Supreme Court's jurisprudence consistently and explicitly stated that the ability to bargain collectively was not a Charter protected activity" (cited in BC Health Services, 
para. 15).

A year later, the British Columbia Court of Appeal dismissed the union's appeal. This Court also relied on the established longstanding precedent set by the Supreme Court of Canada in the Alberta Reference, and reaffirmed that section 2(d) of the Charter did not extend to collective bargaining (Health Services and Support-Facilities Subsector Bargaining Association v. British Columbia [2004] BCCA 377: para. 88). In coming to such reasoning, the Court found that the HEU was still able to negotiate with the government, albeit under the most limited of circumstances.

The HEU then sought leave to appeal to the Supreme Court of Canada, and in June 2007 - in a surprising decision - the Supreme Court overturned the lower courts and its own twenty-year precedent, and asserted that freedom of association as guaranteed by section 2(d) of the Charter includes a procedural right to collective bargaining. This decision was made as a result of the Court's reliance on three main areas: 1) the evolution of Canadian labour history; 2) international labour conventions to which Canada is a signatory; and 3) an expanded notion of Charter values and freedom-of-association rights (BC Health Services, para. 39; see also Walchuk, 2011: 116). What was especially remarkable about the ruling was a "stunning reversal of its previous rulings on the issue" (Tyler, 2007: B1).

Writing for the majority, McLaughlin C.J. and Lebel J. forcefully "conclude[d] that the grounds advanced in the earlier decisions for the exclusion of collective bargaining from the Charter's protection of freedom of association do not withstand principled scrutiny and should be rejected" (para. 22). They went on to assert, "none of the reasons provided by the majorities in those cases survive scrutiny" (para. 36).

The Court built upon the earlier dissenting opinions of Dickson C.J. in the Labour Trilogy and found not only that collective bargaining was a constitutionally protected right, but also pointed to a growing inequality between workers and their employers, and framed collective bargaining as an effective means of addressing this gap. The Court went on to assert:

The protection of collective bargaining under s. 2(d) of the Charter is consistent with and supportive of the values underlying the Charter and the purposes of the Charter as a whole. Recognizing that workers have the right to bargain collectively as part of their freedom to associate reaffirms the values of dignity, personal autonomy, equality and democracy that are inherent in the Charter (para. 82 and 86).

This victory was important for those Canadian workers whose bargaining rights have increasingly been under attack by governments, but has done little to facilitate union growth and expand membership. Furthermore, the Court was clear that Section 2(d) does not guarantee the particular objectives sought through collective bargaining; it merely confirms a right to the process, under which unions may or may not secure their bargaining objectives. The Court maintained:

The right to collective bargaining thus conceived is a limited right. First, as the right is to a process, it does not guarantee a certain substantive or economic outcome. Moreover, the right is to a general process of collective bargaining, not to a particular model of labour relations, nor to a specific bargaining method... (para. 91).

In this light, the Court concluded that unionised workers have the right to unite, to present collective priorities to their employer and to engage in discussions in an attempt to achieve workplace-related priorities, but not necessarily to collective bargaining. 


\section{The Legacy of BC Health Services}

While there has been agreement with the narrow facts of this decision - that the Court found the process of collective bargaining to be part of section 2(d) of the Charter and deserving of constitutional protection - there has been considerable disagreement as to the potential impacts of this decision. In its immediate aftermath, progressive labour law scholars interpreted the impact of this ruling in a number of different ways. For example, Eric Tucker (2008: 174) embraced the ruling, arguing that the Court's decision forced the government to renegotiate with the HEU, which helped to bring about a tentative settlement that provided some remedy to the workers. While recognising many of the limitations to the ruling, Charles Smith (2007:31) encouraged "the labour movement ... [to] rightfully see this as a victory. The court has now affirmed that workers have certain constitutionally protected rights that governments cannot simply legislate away". More critically, Larry Savage (2007: 180) concluded that "far from revolutionary, the Court's decision in Health Services simply shields public sector unions from the worst excesses of neo-liberalism by confirming the public policy environment of the post-war compromise". In this sense, Savage rightly notes that, at best, these important legal victories tend to be defensive in nature and do little to revitalise unions or provide benefit to the majority of workers without a union.

While these scholars disagreed on the potential impacts of the ruling in its immediate aftermath, what can be said of its impacts ten years later? Did it bring about positive benefit for health care workers that were negatively impacted before, and, if so, how? More importantly, did the ruling establish a precedent that has been applied in other cases that have proven useful to other workers facing similar legislation, and, if so, how?

In early 2008, the British Columbia government and the HEU reached an agreement, supported by 94 per cent of the HEU's rank-and-file membership, which addressed the unconstitutional elements and remedied the workers adversely impacted by it. The Court, of course, did not set a remedy - instead leaving that up to the parties and giving them one year to do so - and ruled simply on the constitutionality of the law. The settlement with the HEU, totalling $\$ 75$ million in compensation, was significant and highlighted by $\$ 5$ million to retrain workers laid off as a result of contracting out in the future and $\$ 70$ million in compensation payments to healthcare workers previously affected by the legislation.

The settlement also facilitated union consultation on future plans to contract out services or re-tender services already contracted out, gave them an opportunity to propose alternatives to contracting out, and maintained a cap of 700 full-time equivalents on contracting out. It also provided opportunities for workers laid off as a result of contracting out to apply for job vacancies in health authorities throughout the province (HEU, 2008). The government reached agreements worth $\$ 10$ million with other health unions adversely impacted by the legislation.

Ultimately, there were some costly long-term financial consequences for the government and some sense of justice, though delayed, for the affected workers. Although the settlement was unable to retroactively undo many things, the union was able to go to the negotiating table in 2010 without many of the unconstitutional aspects that it would have faced otherwise. It also helped establish a legal precedent for other workers whose labour rights had been ignored by governments.

Despite the important legal victory, however, the court's ruling that workers have a constitutionally protected right to bargain collectively has not corresponded to an increase in union density. In 2007, the percentage of Canadian workers belonging to a union was 32.4 per cent, and this figure fell to 31.5 per cent by 2014 (StatsCan, 2015). Although the ruling may have benefitted those workers already unionised, it has not translated into increased unionisation rates, and has had negligible impacts on non-unionised workers. 


\section{Building Legal Precedents}

\section{RCMP and SFL}

Federal legislation did not permit members of the Royal Canadian Mounted Police (RCMP) to unionise or to engage in collective bargaining. In 2015, the Supreme Court ruled on a case in which members of the RCMP challenged the constitutionality of this legislation. In Mounted Police Association of Ontario v. Canada (Attorney General), 2015 SCC 1, [2015] 1 S.C.R. 3, RCMP members asserted that, consistent with the precedent established in BC Health Services, they possessed a constitutional right to bargain collectively under section 2(d) of the Charter. The Court agreed with this logic, noting that the case "requires us to review the nature and interpretation of the right guaranteed by s. 2(d) of the Charter and to clarify the scope of the constitutional protection of collective bargaining recognized in Health Services" (para. 1). This represented the first significant case in which unionised workers sought to leverage their position and assert constitutional rights to collective bargaining in the aftermath of $B C$ Health Services.

The RCMP members' appeal to BC Health Services was successful, with the Court concluding that "s. 2(d) guarantees the right of employees to meaningfully associate in the pursuit of collective workplace goals, affirming the central holdings of Health Services and Fraser" (para. 67). ${ }^{1}$ This guarantee includes a right to collective bargaining and that "a process that substantially interferes with a meaningful process of collective bargaining by reducing employees' negotiating power is therefore inconsistent with the guarantee of freedom of association enshrined in s. 2(d)" (para. 71).

While serving as an important victory for workers, the case was not without its shortcomings. The Court reaffirmed that "the right [to bargain collectively] is one that guarantees a process rather than an outcome or access to a particular model of labour relations" (para. 67), and added that their assertion of a right to collective bargaining "does not mandate a particular labour relations regime" (para. 156). In short, while the Court was willing to assert that the Charter protected the right to bargain collectively and that the RCMP's exclusion from formal bargaining rights was unconstitutional, they were unwilling to mandate specific bargaining rights under the Public Service Staff Relations Act and left the door open for another model or avenue of bargaining. Despite the Court's ruling, uniformed RCMP officers still lack access to a regime of collective bargaining despite their legal right to it. At best, the decision will permit access to collective bargaining for the roughly 17000 uniformed RCMP officers who were previously denied it (Statista, 2017), but does nothing to advance the rights of the millions of other workers who are not legally denied bargaining rights.

A week after the Court's decision in RCMP, it delivered another decision in which workers alleged that one of their rights - in this case the right to strike - was constitutionally protected. Perhaps not surprisingly, the decision in Saskatchewan Federation of Labour (SFL) v. Saskatchewan built upon the Court's ruling in BC Health Services. For the Court, at least in 2015, the right to strike went hand-in-hand with the right to bargain collectively. The denial of the right to strike weakened the union's position at the bargaining table, thus undermining their right to bargain collectively. The Court elaborated:

\footnotetext{
1 Ontario (Attorney General) v. Fraser (2011) was a Supreme Court case involving the United Food and Commercial Workers (UFCW) challenging the constitutionality of a piece of legislation that excluded agricultural workers from the Ontario Labour Relations Act and allowed for an alternative (and much weaker) form of associational right. The Court reasoned that bargaining only requires the parties to meet and engage in meaningful dialogue, but does not mandate a particular process, any particular terms, a legislated dispute resolution, and protects only the right "to a general process of collective bargaining, not to a particular model of labour relations, nor to a specific bargaining method" (para. 299).
} 
The right to strike is protected by virtue of its unique role in the collective bargaining process. In Health Services, this Court established that s. 2(d) prevents the state from substantially interfering with the ability of workers, acting collectively through their union, to exert meaningful influence over their working conditions through a process of collective bargaining (para. 77).

After establishing the link between the two rights, aided by their interpretation in $B C$ Health Services, the Court concluded that the government's legislation denied the s. 2(d) rights of unionised employees much more widely and deeply than was necessary to achieve its objective of ensuring the continued delivery of essential service. By virtue of impeding upon a right in a way that was not minimal, the legislation in question violated the workers' right to strike (and right to bargain collectively). This was the first time that the Court found that the Charter protected the right to strike, and their decision in BC Health Services certainly aided this finding.

More specifically, the Court was particularly concerned with the legislation's prohibition of unilaterally designated essential services employees from participation in any strike action, the lack of a process of appeal regarding the essential services designation, and the absence of a meaningful mechanism for resolving bargaining impasses (such as binding arbitration). In this sense, the Court found the legislation in question to be "uniquely restrictive" (para. 19).

Reflecting upon the Court's decision in these cases, Charles Smith (2015) rightly contends that there were tangible benefits to the Court's ruling. It did not merely impede the government's broader legislative goals; it would also have the effect of providing something of substance to the affected unions. On a much broader level, the decision gave weight to the assertion that labour rights are human rights deserving of constitutional protection. This was certainly the opinion of Canadian Labour Congress (CLC) president Hassan Yussuff (2015), who congratulated the Supreme Court of Canada for its "courageous decision" in recognising labour rights under the Charter. In commenting on the potential impact of an expanded view of workers' rights as human rights, Smith elaborated:

[The proponents of this see] constitutional rights act[ing] as a buffer to protect unions from further attacks by neoliberal governments. In essence, constitutional protection will act as a legal shield to protect labour's existing rights and lay the foundation to grow and expand the labour movement in new ways (Smith, 2015: n.p.).

It remains difficult to see, however, how this facilitates growth and expansion for the labour movement. Union density has remained relatively stable since the decision, and the right to strike applies only to those who belong to an existing union. The legal strategy here has proven to be defensive, and does not contribute to a strategy based on organising and mobilising.

It remains to be seen, however, what would occur if a more muted piece of legislation were introduced, such as one that prohibited the right to strike but that allowed workers to challenge an essential services designation through a neutral process and allowed for dispute resolution of any bargaining impasse by a mutually agreeable arbitrator.

\section{Bill 115 in Ontario}

In 2012, the Ontario government passed the Putting Students First Act (commonly known as Bill 115), which allowed the provincial government to set rules that local school boards needed to follow when negotiating with local unions. The bill also limited wage increases, eliminated sick pay entitlements and allowed the government to impose a collective agreement on school boards and various unions representing education workers if negotiations were not completed by a set date 
(Alphonso, 2016). In addition to a series of rotating strikes and a mass protest outside the governing Liberal Party's convention in early 2013, the unions initiated a constitutional challenge, asserting that the legislation was a violation of the workers' constitutional right to bargain collectively. ${ }^{2}$

On 20 April 2016, the Ontario Superior Court of Justice determined that "between the fall of 2011 and the passage of the Putting Students First Act, Ontario infringed on the applicants' right, under the Charter of Rights and Freedoms, to meaningful collective bargaining" (para. 134). After an examination of an expanded notion of constitutionally protected collective bargaining rights, the Court noted, "it becomes apparent that the process engaged in was fundamentally flawed. It [the Putting Students First Act] could not, by its design, provide meaningful collective bargaining" (para. 135).

The process established under the legislation was flawed from the start, in that it set a goal (fiscal restraint) and then established a process (the denial of bargaining rights) by which that goal would to be realised. To this end, the Court was critical of the government's process that "set the parameters which would allow it to meet fiscal restraints it determined and then set a program which limited the ability of the others parties to take part in a meaningful way" (para. 135). A right to bargain collectively mandated that other parties (unions and their members) have a role in the process and have the ability to engage in meaningful negotiations. By this point, the precedent from $B C$ Health Services was apparently enough, so that the Ontario government did not seek leave to the Supreme Court of Canada and instead followed the Court's mandate that they engage in negotiations with the affected unions to rectify the rights abuse.

After months of negotiation, the Canadian Union of Public Employees (CUPE) agreed to a $\$ 56.7$ million legal settlement in "what may be one of the largest settlements of its kind for employees who have suffered a workplace breach of Charter rights" to compensate against their members' losses resulting from Bill 115 (CUPE, 2017). This was in addition to the roughly $\$ 50$ million paid to the province's public high school teachers (members of the Ontario Secondary School Teachers Federation, OSSTF), and $\$ 2.75$ million paid to school support staff represented by the Ontario Public Service Employees Union (OPSEU) (Rushowy, 2017; Waddell, 2017). The logic, of course, is that by stripping the workers of their bargaining power, it greatly weakened their position in relation to the employer. This likely explains why the government would have proceeded with such legislation in light of $B C$ Health Services and subsequent rulings on constitutionally protected workers' rights. It allowed the government to secure their goals - labour peace in the lead-up to an election and a favourable position at the bargaining table - and worry about the fallout later.

These large settlements reflect that free and fair collective bargaining should not simply be seen merely as an issue of dollars and cents, but rather reflects the fact the workers lost their constitutional right to bargain, regardless of what they could have achieved at the bargaining table had they been able to bargain. These settlements attempt to mitigate against such losses. The province remains in negotiations with the Elementary Teachers' Federation of Ontario (ETFO), which represents roughly 78000 teachers who were also adversely impacted by Bill 115 .

Of the settlement, Terri Preston, chair of CUPE's Education Sector Coordinating Committee, noted:

We are pleased to finally have reached agreement on monetary recognition that the Ontario government violated our basic Charter rights ... Bill 115 should never have been introduced in the

2 The affected education unions were the Elementary Teachers Federation of Ontario, the Ontario Secondary School Teachers Federation, the Ontario Public Service Employees Union and the Canadian Union of Public Employees. 
first place. Justice Lederer's decision gave us the ability to negotiate redress for our members (CUPE, 2017).

It also remains clear that the labour movement is well aware of the growing jurisprudence in the area of labour rights. Unions have a broader strategy of building precedent in cases around labour rights and applying that precedent in future cases. "CUPE's interest in this was clear from the start”, said Mark Hancock, the union's National President. He added:

Even before the Bill 115 case was heard, CUPE took the lead in pushing the Saskatchewan Federation of Labour case forward. In that case, the Supreme Court of Canada found the Saskatchewan government had gone too far in its attempt to ban strikes. In the Bill 115 case, we argued - and Justice Lederer agreed - that in giving the Ontario government the ability to prohibit strikes, the Bill violated the Charter. Taken together, these cases are building a strong body of jurisprudence in Canada that confirms workers' Charter right to freedom of association (CUPE, 2017: n.p.).

In this sense, unions are making a strategic decision to embrace a legal strategy, and while this may provide benefit to existing unions, it does not have the capability to facilitate growth or a broader mobilisation strategy.

That said, the Bill 115 settlements represents one of the most recent, and most costly, settlements for violating the constitutionally protected right of workers to bargain collectively. This suggests that while governments can still violate rights - at least in the interim - there are potentially significant financial costs for doing so. Settlements like this would not be possible had it not been for the Supreme Court's decision in BC Health Services affirming a constitutional right to bargain collectively. It is likely that governments would have continued to run roughshod over workers' legislative rights, without the corresponding financial obligation that is associated with violating those rights. This is especially important as stagnant union density and a reliance on legal procedures limits broader mobilisation techniques. A weakened and defensive labour movement even one with constitutionally protected rights - is an easy target for neo-liberal governments. At worst, those governments will have to pay a penalty for violating rights, but will not need to contend with a growing and mobilised movement.

\section{Budget Implementation Act, 2013}

Shortly after the Ontario Superior Court's decision on Bill 115, the federal government repealed elements of the Second act to implement certain provisions of the budget tabled in Parliament on March 21, 2013 and other measures (hereinafter Bill C-4). This legislation, passed by the previous federal government, provided the employer the exclusive right to designate essential services provisions and to exercise that right at any time, altered unions' access to arbitration and mandated arbitrators to ensure that the "prudent use of public funds are sufficient to allow the employer to meet its operational needs ... relative to [the government's] stated budgetary policies" (Parliament of Canada, 2013). This legislation became the subject of a Charter challenge by federal-sector unions (CIU, 2014). The decision to repeal the legislation, celebrated by federal-sector unions, was in part informed by a growing jurisprudence of labour rights being protected by the Charter (CLC, 2017).

\section{The British Columbia Teachers' Federation}

The most recent major Charter victory for unions claiming a human rights violation occurred in 2016. The Supreme Court of Canada's decision in British Columbia Teachers' Federation v. British 
Columbia (2016) was the culmination of a fourteen-year legal battle between the government and the British Columbia Teachers' Federation (BCTF). At issue was legislation that stripped existing provisions from collective agreements related to classroom conditions, notably class size and teaching complement, and prohibited the union from bargaining over these. The Supreme Court ruling confirmed lower court rulings, one of which awarded the BCTF $\$ 2$ million in damages. In reality, however, the impact of the unconstitutional legislation was much greater, with the BCTF estimating the loss of roughly 3500 full-time jobs since 2002; it cost between $\$ 250$ million and $\$ 300$ million a year (largely in wages) to restore class limits and other provisions of previous contracts (Stueck, 2016). The lengthy legal battle illustrated a clear union preference for a legalised strategy as opposed to one based predominantly on membership mobilisation and collective action.

In commenting on this case, and the Court's very brief decision (a single paragraph posted to its website, allowing the appeal from the union), Joel Bakan remarked that the Court had been "quite bullish" in protecting workers' rights under the Charter in recent years and that in this case "the seven majority judges looked at it and said, 'We've spoken already, we've articulated what the law is, we don't need to do it again"' (cited in Stueck, 2016: n.p.).

To be sure, the fact that basic bargaining rights were not adhered to by the British Columbia government, and were twice ruled to be unconstitutional by lower courts, suggests that the constitutional rights of unionised workers are often seen as burdensome and secondary to the government's broader goals, in this case fiscal restraint and a broader dismantling of public education (Miller, 2015). The settlement from this case and the Court's clear decision provided an important advancement of the notion of labour rights in Canada, though one that falls well short of even beginning to revitalise the labour movement.

\section{The Current State of Collective Bargaining Rights}

The evolution of seeing labour rights as constitutional rights has been a slow process, beginning in 1987 with the dissenting opinion of Chief Justice Dickson, which was then expanded on by a majority opinion in BC Health Services. Unions, facing infringements on their collectively held legislative rights and declining union density, relied upon a legal strategy and the precedent from the ground-breaking decision in BC Health Services, which was then applied in MPAO, SFL, BCTF and with Bill 115. Unions hope to expand it even further.

As the above cases illustrate, there has certainly been an advancement in the notion of collectively held rights for unionised workers since $B C$ Health Services (though the same cannot be said for non-unionised workers). That these rights are constitutionally protected, as opposed to simply legislatively permitted, is a present reality and supported by a growing body of jurisprudence. As a result, it is likely that unions will continue to make rights-based appeals under the Charter when faced with legislation that appears to infringe upon their collective rights. There has yet to be an indication that a majority of the Court will retreat from the precedent established in $B C$ Health Services, and there has yet to be an indication that unions will move away from their legal strategy.

Problematically, however, the Court's decision simply mandates a process and establishes a penalty for denying access to that constitutionally protected process. It offers little hope to nonunionised workers hoping to join a union, and has not appeared to have contributed to improving Canada's stagnant union density. Despite finding that collective bargaining is constitutionally protected, there is no way to ensure that governments will ensure the ongoing realisation of this right, and the Court has made it clear that there are limits to labour rights. Indeed, the precedent from BC Health Services seemed clear at the time of the passage of Bill 115, but the government proceeded nonetheless, as they often do when they believe it to be politically advantageous, 
expedient or strategic.

This suggests that despite the decision in BC Health Services, infringements on constitutionally protected rights still exist (and will likely continue to exist), though the Ontario government's decision not to seek leave to the Supreme Court regarding Bill 115 illustrates that governments are beginning to understand that rights exists and that there are costly repercussions to their actions. The settlements emanating from the decision in Bill 115 also illustrate that there are financial penalties for such violations, which should - in theory - serve as a disincentive to further rights violations. However, in the face of a defensive labour movement with a stagnant membership, governments may continue to play hardball and let the courts sort things out, particularly if unions are unwilling to use their constitutionally protected right to strike with vigour.

More critically, however, these settlements may simply illustrate that rights violations can be monetised. This suggests that as long as some sort of settlement is budgeted for, a government may elect to proceed with its legislative goals, regardless of their constitutionality. This may be especially true if moving forward ensures that some other goal (such as ending an unpopular strike, appearing to take a strong stand, etc.) is secured, or that a settlement costs less than bargaining in good faith. For example, OSSTF President Paul Elliott noted that the settlements - which appear to be sizeable at first glance - pale in comparison with what could have been secured through free and fair collective bargaining. He classified the settlements as "kind of a token as opposed to what was taken out of the contract", adding that "at the end of the day, they took over a billion dollars out and they are paying pennies on that. It's a big difference between a billion dollars and $\$ 50$ million" (quoted in Rushowy, 2017: n.p.). If there is, in fact, a savings of hundreds of millions of dollars from violating collective bargaining rights and then providing a settlement of a portion thereof in the future, governments may decide to push ahead with their legislative agenda, regardless of its constitutionality. At the same time, even if the government expects to have to pay something at some point, they may find it worthwhile to gamble that a Court will order them to pay less, or at the very least set aside a reasonable sum and let it accrue interest to help offset the cost when it is paid.

Despite the important precedent established in recent cases since BC Health Services, there remain important shortcomings in the Court's treatment of intrusions into the collective bargaining process and the labour movement's ability to rely on the judiciary to secure its rights. Litigation on the federal government's Expenditure Restraint Act, which imposed a wage rollback from previously agreed-to wages, was found not to be in violation of the Charter as it was "time-limited in nature, were shared by all public servants, and did not permanently remove the subject of wages from collective bargaining" (Meredith v. Canada (Attorney General), para. 27). This suggests that there are permissible instances for the legislature to infringe upon rights that the Court will likely find to be consistent with the Charter.

Despite this setback, it appears that organised labour will continue to utilise the Charter to protect their members' interests. For example, a coalition of unions in Manitoba known as the Partnership to Defend Public Services is mounting a legal challenge to the Conservative government's Bill 28, which unilaterally imposes a public-sector wage freeze. Unifor's Western Regional Director Joie Warnock asserts, "Premier Pallister wants to strip workers of constitutionally-protected rights", adding that "it failed in Saskatchewan under Brad Wall, and it will fail again with the PC government in Manitoba" (Unifor, 2017: n.p.). The implication here is that the matter will simply be diverted to the courts rather than being fought through broad member mobilisation. This highlights the defensiveness of a legal strategy and its limits at facilitating membership mobilisation and further growth.

Similarly, in response to the Ontario government's decision to legislate striking college 
professors back to work in 2017 and to send the outstanding issues to binding arbitration, the Ontario Public Service Employees Union announced a Charter challenge. President Smokey Thomas stated, "For over a decade, the Supreme Court of Canada has viewed collective bargaining as a protected right under the Charter", adding that "the government trampled on the right to collective bargaining when they clearly had other choices" (OPSEU, 2017: n.p.). Likewise, CUPE (2018) has expressed concern about its teaching assistants in Local 3903 being legislated back to work in 2018. In fact, CUPE asserted that the employer (a publicly funded university) had no intention to secure a meaningful deal with the union, claiming that "Back-to-work legislation is what York [University] has wanted from the beginning. They've basically refused to bargain and now Premier Ford is letting them off the hook" (CUPE, 2018: n.p.).

This provides more support to back-to-work legislation serving as a final trump card held by the legislature, regardless of what judicial precedence suggests. This in turn allows rights to be eroded, if only temporarily, and allows governments to secure short-term gain or to make a fiscal decision about the value of settling versus the potential of the Court mandating some sort of settlement. This is particularly true for back-to-work legislation passed in 2018 against CUPE Local 3903, which allowed the newly elected government to fulfil an election promise of ending the strike and to make a tough stand against labour in the process, despite the dubious legality of the legislation. At the very least, the strike and striking workers lose their momentum and, quite likely, whatever is settled upon would be less than what could have been achieved had they been allowed to remain on strike and settle on their terms.

Despite this shortcoming, the overall trend in the past decade seems to validate Savage and Smith's (2017: 207) assertion that "in the wake of landmark Supreme Court decisions in BC Health Services, MPAO, and SFL v. Saskatchewan, organized labour has clearly become more emboldened to make broader rights-based claims on behalf of union members and the working class more generally". Only time will fully tell how successful this strategy is and if it is capable of securing rights, as opposed to simply monetising their violations. At this point, these rights-based claims have provided important benefits to some union members, but has yet to offer much to nonunionised workers. There is no evidence that the reliance on the courts has led to union revitalisation. To be sure, unions are actively organising new members, but having constitutionally protected rights does not appear to be incentive enough to convince workers to join the labour movement.

\section{Conclusion}

The decision in BC Health Services as well as the cases over the past decade which have relied upon its precedent signal a significant shift away from the Court's approach in the Labour Trilogy. Despite what appear to be important gains, it is essential that we reflect upon their broader impacts. Savage and Smith (2017: 210), for example, highlight some of these shortcomings, noting "elitedriven victories threaten, over time, to depoliticize class-based struggles that have historically advanced the cause of working people". Despite this warning, the rights-based campaigns in Saskatchewan and Ontario, noted above, show that labour will continue to utilise the Charter to protect and advance the rights of its members.

While the legal victories in $B C$ Health Services and subsequent cases have certainly been important, labour cannot rely solely on a legal approach and must assert its political power at the bargaining table, the ballot box, the picket line and in the community to advance a transformative political agenda, particularly in an era of neo-liberalism. As Savage (2007: 68) warned previously, "the labour rights as human rights approach threatens to undermine class-based responses to 
neoliberal globalization by contributing to the depoliticization of the labour movement" (see also Walchuk, 2011). Indeed, a strategy driven by litigation is at best a double-edged sword, presenting political shortcomings, even if it leads to legal victories.

Even when successful, such a strategy fails to provide direct benefits to non-unionised workers and does not lead to growth within the labour movement, something especially needed in a time of stagnant union density. While the judiciary has advanced labour's legal rights in the decade since the $B C$ Health Services decision, workers have yet to embrace unionisation. As a result, the labour movement has not been revitalised, and governments still show a willingness to violate basic labour rights, if only out of political expediency and/or a decision that any financial penalty will be worth the infringement (and perhaps even cheaper than settling in good faith to begin with). Furthermore, the Supreme Court's decision in the Expenditure Restraint Act shows that the judiciary is never predictable, and labour cannot rely too heavily upon it, even in this relatively robust post-BC Health Services era. This is true both in Canada and globally.

\section{REFERENCES}

Adams, Roy J. (2006) Labour Left Out: Canada's Failure to Protect and Promote Collective Bargaining as Human Right. Ottawa: Canadian Centre for Policy Alternatives.

Alphonso, Caroline (2016) Sick Days Costing Ontario School Boards \$1-billion a Year, Report Says. The Globe and Mail. < https://www.theglobeandmail.com/news/toronto/sick-days-costing-ontario-schoolboards-1-billion-a-year-report-says/article29413702/> [accessed 24 December 2017].

Beherens, Martin, Kerstin Hamann and Richard W. Hurd (2004) Conceptualizing Labour Union Revitalization. Cornell University ILR Digital Commons. <https://core.ac.uk/download/pdf/144989238.pdf> [accessed 7 August 2018].

Brody, David (2001) Labor Rights as Human Rights: A Reality Check. British Joumal of Industrial Relations, 39(4): 601-605.

Canadian Foundation for Labour Rights (CFLR) (2017) Restrictive Labour Laws in Canada.

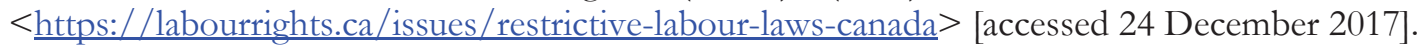

Canadian Labour Congress (CLC) (2017) Canada's Unions Celebrate Repeal of Controversial Anti-union Legislation. $<\underline{\text { http: } / / \text { canadianlabour.ca/news/news-archive/canada } \% \mathrm{E} 2 \% 80 \% 99 \text { s-unions-celebrate-repeal- }}$ controversial-anti-union-legislation> [accessed 24 December 2017].

Canadian Union of Public Employees (CUPE) (2017) CUPE Education Workers Reach Agreement on Bill 115 "Remedy" with Provincial Government. < https://cupe.ca/cupe-education-workers-reach-agreement-bill115-remedy-provincial-government> [accessed 24 December 2017].

Canadian Union of Public Employees (CUPE) (2018) Ford Government Begins its Mandate by Violating Workers' Rights. <https://cupe.ca/ford-government-begins-its-mandate-violating-workers-rights $>$ [accessed 7 August 2018].

Colling, Trevor (2009) Court in a Trap? Legal Mobilisation by Trade Unions in the United Kingdom. Warwick Papers in Industrial Relations, No. 91. < https://warwick.ac.uk/fac/soc/wbs/research/irru/wpir/wpir 91.pdf $>$ [accessed 24 December 2017].

Compa, Lance (2000) Unfair Advantage: Worker's Freedom of Association in the United States under International Human Rights Standards, A Human Rights Watch Report. < $\underline{\text { http://www.hrw.org/legacy/reports/ }}$ 2000/uslabor/> [accessed 24 December 2017].

Customs and Immigration Union (CIU) (2014) PSAC Launches Court Action Against Bill C-4. $<$ https://www.ciu-sdi.ca/2014/03/psac-launches-court-action-against-bill-c-4/> [accessed 7 August 2018].

Frege, Carola and John Kelly (2004) Varieties of Unionism: Strategies for Union Revitalization in a Globalizing Economy. Oxford: Oxford Scholarship. 
Fudge, Derek (2006) Collective Bargaining in Canada: Human Right or Canadian Illusion? Second edition. Halifax: Fernwood Publishing.

Gender and Work Database (2012) Strikes and Lockouts in Canada, 1960-2009. < http://www.genderwork. ca/gwd/wp-content/uploads/hrsdc table-11.pdf> [accessed 24 December 2017].

Gross, James A. (2003) A Long Overdue Beginning: The Promotion and Protection of Worker's Rights as Human Rights. In Workers' Rights as Human Rights, edited by James Gross. Ithaca, NY: Cornell University Press.

Guillaume, Cecile (2015) Understanding the Variations of Unions' Litigation Strategies to Promote Equal Pay: Reflection on the British Case. Cambridge Journal of Economics, 39(2): 363-379.

Hospital Employees Union (HEU) (2008) HEU Members Approve Bill 29 Settlement. $<$ https://www.heu.org/news-media/news-releases/heu-members-approve-bill-29-settlement> [accessed 24 December 2017].

IndustrialALL (2018) South Africa: Union in Historic Court Victory Against Precarious Work. $<$ http:// www.industriall-union.org/south-africa-union-in-historic-court-victory-against-precariouswork $>$ [accessed 7 August 2018].

Isitt, Benjamin and Melissa Moroz (2007) The Hospital Employees' Union Strike and the Privatization of Medicare in British Columbia, Canada. International Labor and Working-Class History, 71: 91-111.

Lancaster House (2007) Supreme Court Watch - Recent Decisions: Health Services and SupportFacilities Subsector Bargaining Assn. v. British Columbia (2007). < http://www.lancasterhouse.com/supreme Lrecent health.asp> [accessed 24 December 2017].

Lévesque, Christian and Gregor Murray (2010) Understanding Union Power: Resources and Capabilities for Renewing Union Capacity. Transfer: European Review of Labour and Research, 16(3): 333-350.

Lichtenstein, Nelson (2003) The Rights Revolution. New Labor Forum, 12(1): 61-73.

Liptak, Adam (2018) Supreme Court Ruling Delivers a Sharp Blow to Labor Unions. New York Times, 27 June 2018. <https://www.nytimes.com/2018/06/27/us/politics/supreme-court-unions-organizedlabor.html> [accessed 7 August 2018].

Mandel, Michael (1994) The Charter of Rights and the Legalization of Politics. Revised edition. Toronto: Thompson Educational Publishing.

McCartin, Joseph (2005) Democratizing the Demand for Workers' Rights: Toward a Re-Framing of Labor's Argument. Dissent, Winter 2005: 61-71.

Miller, Sarah (2015) Dear Christy Clark: Stop Relying on Parents, Teachers to Fund B.C. Public Schools. Huffington Post. $<$ https://www.huffingtonpost.ca/sarah-miller2/dear-christy-clark-bc-schools b 7088 508.html> [accessed 24 December 2017].

Ontario Public Service Employees Union (OPSEU) (2017) OPSEU to File Charter Challenge over College Backto-work Law. <https://opseu.org/news/opseu-file-charter-challenge-over-college-back-work-law $>$ [accessed 24 December 2017].

Panitch, Leo and Donald Swartz (2003) From Consent to Coercion: The Assault on Trade Union Freedoms. Third edition. Aurora, Ont.: Garamond Press.

Parliament of Canada (2013) A Second Act to Implement Certain Provisions of the Budget Tabled in Parliament on March 21, 2013 and Other Measures. <http://www.parl.ca/DocumentViewer/en/41-2/bill/C-4/royalassent/page-4> [accessed 24 December 2017].

Rushowy, Kristin (2017) Court Settlement with High School Teachers will Cost Ontario Government about $\$ 50$ million. Toronto Star, 3 May 2017. < https://www.thestar.com/news/queenspark/2017/05/03 Lcourt-settlement-with-high-school-teachers-will-cost-ontario-government-about-50-million.html> [accessed 24 December 2017].

Savage, Larry (2007) Organized Labour and the Canadian Charter of Rights and Freedoms. The Supreme Court Law Review, second series. 36: 175-199. 
Savage, Larry (2008) Labour Rights as Human Rights? A Response to Roy Adams. Just Labour: The Canadian Journal of Work and Society, 12: 68-75.

Savage, Larry and Charles Smith (2017) Unions in Court: Organized Labour and the Charter of Rights and Freedoms. Vancouver: UBC Press.

Smith, Charles (2007) Supreme Court Shifts on Right to Bargain. Relay: A Socialist Review Project, 18 (July/August): 31.

Smith, Charles (2015) The Politics of the Constitutional Right to Strike. Rank-and-File, 3 February 2015. $<$ http://rankandfile.ca/2015/02/03/the-politics-of-the-constitutional-right-to-strike/> [accessed 24 December 2017].

StatsCan (2015) Labour Organizations in Canada 2015. < https://www.canada.ca/en/employment-socialdevelopment/services/collective-bargaining-data/reports/union-coverage.html> [accessed 24 December 2017].

StatsCan (2018) Unionization Rates Falling. <https://www150.statcan.gc.ca/n1/pub/11-630-x/11-630x2015005-eng.htm $>$ [accessed 7 August 2018].

Statista (2017) Number of Royal Canadian Mounted Police officers in Canada in 2017, by level of policing and province. <https://www.statista.com/statistics/436207/number-of-royal-canadian-mountedpolice-officers-in-canada $>$ [accessed 24 December 2017].

Stueck, Wendy (2016) B.C. Teachers' Union Wins Landmark Appeal at Supreme Court. The Globe and Mail. $<$ https://www.theglobeandmail.com/news/british-columbia/bc-teachers-union-wins-landmarkappeal-at-supreme-court/article32793770> [accessed 24 December 2017].

Sugeno, Kazuo (2015) The Significance of Labour Relations Commissions in Japan's Labor Dispute Resolution System. Japan Labor Review, 12(4). <https://www.jil.go.jp/english/JLR/documents/2015/ JLR48 sugeno.pdf> [accessed 24 December 2017].

Tucker, Eric (2008) The Constitutional Right to Bargain Collectively: The Ironies of Labour History in the Supreme Court of Canada. Labour/Le Travail: Journal of Canadian Labour Studies, 61: 151-180.

Tyler, Tracey (2007) Top Court Protects Bargaining. Toronto Star, 9 June 2007: B1.

Unifor (2017) Unifor Challenges Manitoba's Anti-union Law. <http://unifor.org/en/whats-new/news/ unifor-challenges-manitobas-anti-union-law $>$ [accessed 24 December 2017].

Waddell, Dave (2017) Province to Pay Millions to Settle Lawsuit over Bill 115. Windsor Star. $<$ http://windsorstar.com/news/local-news/province-to-pay-millions-to-settle-lawsuit-over-bill-115> [accessed 24 December 2017].

Walchuk, Brad (2008) The Best of Both Worlds: A Pragmatic Approach to the Construction of Labour Rights as Human Rights. Just Labour: Canadian Journal of Work and Society, 14: 75-91.

Walchuk, Brad (2011) Union Democracy and Labour Rights: A Cautionary Tale. Global Labour Journal, 2(2): 106-124.

Weiler, Joseph M. (1986) The Regulation of Picketing under the Charter. In Litigating the Values of the Nation: The Canadian Charter of Rights and Freedoms, edited by Robin M. Elliot. Toronto: Carswell.

Yussuff, Hassan (2015) With Right to Strike, the Supreme Court Returns Balance to the Workplace. The Globe and Mail. < https://www.theglobeandmail.com/opinion/with-right-to-strike-the-supreme-courtreturns-balance-to-the-workplace/article22722756> [accessed 24 December 2017].

\section{Case Law}

British Columbia Teachers' Federation v. British Columbia, 2016 SCC 49, [2016] 2 S.C.R. 407

Dunmore v. Ontario (Attorney General), 2001 SCC 94, [2001] 3 S.C.R. 1016

(The) Health Services and Support-Facilities Subsector Bargaining Association et. alv. Her Majesty the Queen et. al., (2003) BCSC 1379 
Health Services and Support-Facilities Subsector Bargaining Association v. British Columbia 2004 BCCA 377

Health Services and Support-Facilities Subsector Bargaining Association v. British Columbia. (2007). 2 S.C.R. 391, 2007 SCC 27.

Meredith v. Canada (Attorney General), 2015 SCC 2, [2015] 1 S.C.R. 125

Ontario (Attorney General) v. Fraser, 2011 SCC 20 (2011) 2 S.C.R. 3

OPSEU v Ontario, 2016 ONSC 2197

Mounted Police Association of Ontario v. Canada (Attorney General), 2015 SCC 1, [2015] 1 S.C.R. 3

PSAC v. Canada, 1987$] 1$ S.C.R. 424

Reference Re Public Service Employee Relations Act (Alta.), [1987] 1 S.C.R. 313

R.W.D.S.U. v. Saskatchewan, [1987] 1 S.C.R. 460

R.W.D.S.U., Local 558 v. Pepsi-Cola Canada Beverages (West) Ltd., [2002] 1 S.C.R. 156, 2002 SCC 8

Saskatchewan Federation of Labour v. Saskatchewan, 2015 SCC 4, [2015] 1 S.C.R. 245

U.F.C.W., Local 1518 v. KMart Canada Ltd., [1999] 2 S.C.R. 1083

\section{BIOGRAPHICAL NOTE}

BRAD WALCHUK works for a public sector union representing higher education workers in Hamilton, Canada. On occasion he also teaches in the Department of Labour Studies at Brock University, from where he holds a Master's degree in Political Science. He recently completed the AFL-CIO's Corporate Strategic Research course at Cornell University. [Email: bw3906@gmail.com] 